\title{
Altered Intracellular Calcium in Fibroblasts from Patients with Cystic Fibrosis and Heterozygotes
}

\author{
ROBERT J. FEIGAL AND BURTON L. SHAPIRO
}

Department of Oral Biology, H.S. Unit A 17-226, University of Minnesota, Minneapolis, Minnesota, USA

\begin{abstract}
Summary
The importance of intracellular calcium $(\mathrm{Ca})$ in secretion and transmembrane ion movement led us to study $\mathrm{Ca}$ in cells from patients with cystic fibrosis (CF) which is a lethal genetic exocrinopathy. Skin fibroblasts from patients with $\mathrm{CF}$, obligate heterozygotes (HZ), and age- and sex-matched controls (C) were used in matched pair experiments measuring ${ }^{45} \mathrm{Ca}$ exchange into and efflux from the cells over time. CF cell lines and $\mathrm{HZ}$ cell lines exhibit increased ${ }^{45} \mathrm{Ca}$ exchange when compared with their respective controls $(P<0.005)$. The magnitude of this difference (approximately $30 \%$ ) is not reduced when cells are washed with lanthanum chloride after the exchange period. This difference is likely attributable to an altered capacity of one or more of the intracellular Ca sequestering organelles. Further evidence for this explanation was seen in ${ }^{45} \mathrm{Ca}$ efflux experiments in which CF cells retained a higher percent of their initial 0-time ${ }^{45} \mathrm{Ca}$ than did $\mathrm{C}$ cells late in the efflux period $(P<0.05)$. The finding of an altered $\mathrm{Ca}$ pool size in both $\mathrm{CF}$ and particularly $\mathrm{HZ}$ cells suggests that altered Ca metabolism is related to the basic gene defect in CF.
\end{abstract}

\section{Speculation}

Increased intracellular $\mathrm{Ca}$ in $\mathrm{CF}$ cells, while necessarily secondary to the basic gene defect, may influence cellular metabolism sufficiently to be a basis for many events in the pathogenesis of the disease. The presence of the Ca pool size alteration in cells from obligate heterozygotes is evidence that this phenomenon is closely related to the basic gene defect.

CF is a lethal genetic exocrinopathy. The most apparent symptoms are chronic obstructive lung disease and gastrointestinal malabsorption. With one or both of these, the definitive diagnostic sign is elevated sweat chloride. This autosomal recessive trait affects approximately one in 1600 Caucasian newborns and has a carrier frequency of about one in 20 in Caucasian populations (20). While secretory anomalies in some exocrine glands of patients with CF have been reported, the metabolic basis for the disease is unknown.

$\mathrm{Ca}$ homeostasis involves carefully controlled systems that include transport and sequestration by cell membranes and intracellular organelles. Alterations in this homeostasis may cause changes in many associated intracellular systems. Regulation of cellular $\mathrm{Ca}$ by plasma membrane and intracellular organelles is recognized as a modulating factor in stimulus-secretion coupling, stimulus-contraction coupling, activation of several enzymes, and hormonal regulation $(8,24)$.

Altered $\mathrm{Ca}$ concentrations have been observed in some exocrine secretions from $\mathrm{CF}$ patients (9). Increased levels of $\mathrm{Ca}$ in submandibular saliva has been consistently confirmed $(2,28)$. Ca concentration in tears was found to be higher in subjects with $C F$ than in their sibs (7). There were early suggestions concerning the role of increased $\mathrm{Ca}$ in $\mathrm{CF}$ pathogenesis (10). It was thought that increased $\mathrm{Ca}$ in secretions might lead to less soluble $\mathrm{Ca}$-glycoprotein complexes and that subsequent precipitates cause tissue ob- struction. Increased $\mathrm{Ca}$ will lead to increased fluid viscosity, but no progress in this relationship has occurred $(10,16)$. According to Di Sant'Agnese and Davis (9), there is little clinical evidence to suggest a $\mathrm{Ca}$ metabolic disorder in CF.

Recently, the role of $\mathrm{Ca}$ in the rabbit tracheal mucociliary bioassay system has been examined (3). A CF-like response was found when the $\mathrm{Ca}$ ionophore $\mathrm{A} 23187$ was added to the bathing medium. This response was abolished by $\mathrm{Ca}$ chelation with EGTA. A23187, when added to control sera, gave a CF-like response. EGTA eliminated the CF-like response when added to $\mathrm{CF}$ sera. Bogart (3) concluded that $\mathrm{Ca}$ is an important cofactor in the CF sera-induced rabbit tracheal mucociliary assay. Using isolated rat parotid acinar cells in vitro, CF saliva and a solution containing A23187 caused increased intracellular Ca in comparison with cells incubated in saliva from control subjects (21).

Until the report from this laboratory (26), relatively little and nothing definitive has appeared concerning intracellular $\mathrm{Ca}$ in $C F$. Fletcher and Lin (14) found no difference in the time course of $\mathrm{Ca}$ uptake by skin fibroblasts from one CF subject with whom they compared cells from one control. The use of glass coverslips as a substrate for their monolayers could have led to binding of much of the added $\mathrm{Ca}$ to negatively charged glass, thus, obscuring differences that might have existed. They did not preequilibrate with a cold $\mathrm{Ca}$ medium which we found to be a necessary condition to distinguish $C F$ and carrier monolayers from the respective controls. In a preliminary study using X-ray spectroscopy (1), three pooled samples, one each of $\mathrm{CF}$, carrier, and control fibroblast lines were examined: CF fibroblasts showed a greater Ca peak. Similarly, dissociated parotid acinar cells from CF subjects showed increased $\mathrm{Ca}$ and sodium in comparison with controls (21). The role of $\mathrm{Ca}$ in stimulus-secretion coupling (11, 24) and its relationship to the transport of sodium and hydrogen ions (19) suggested to us its potential involvement in critical events in $\mathrm{CF}$.

Although fibroblasts are not exocrine cells, they are classically secretory cells. For this reason, as well as the ability to generate large numbers of genetically stable cells from small skin biopsies, we are using skin fibroblasts as a model system to study CF.

This report involves experiments on $\mathrm{Ca}$ exchange in fibroblasts from $\mathrm{CF}$ subjects, obligate $\mathrm{HZ}$ and their respective controls in which an unspecified intracellular $\mathrm{Ca}$ pool is observed to be markedly increased in $\mathrm{CF}$ and $\mathrm{HZ}$ cells.

\section{METHODS AND MATERIALS}

Skin fibroblasts obtained by biopsy of the medial surface of the upper arm were used to establish cell lines. Outpatients under care at the University of Minnesota CF Center were used as donors for CF lines while age- and sex-matched controls were people not under treatment for any illness. Parents of patients with CF were used to establish $\mathrm{HZ}$ cell lines, and age- and sex-matched controls were obtained for these lines also. Fibroblasts were routinely maintained in Eagles minimal essential medium with Earles salts plus L-glutamine, supplemented with $10 \%$ fetal calf serum, 100 units per $\mathrm{ml}$ of penicillin, and $100 \mu \mathrm{g} / \mathrm{ml}$ of streptomycin. Cells 
were cultured in a humidified atmosphere of $5 \% \mathrm{CO}_{2}$ in air at $37^{\circ} \mathrm{C}$, and were subcultured weekly with $0.5 \%$ trypsin plus $0.8 \%$ sodium citrate. Cells from each line were frozen and stored in liquid nitrogen for future use.

Cells were used between the third and the twelfth passage for all experiments. Multiwell trays (Linbro Plastics, Hamden, CN) with $24-1.5 \mathrm{~cm}$ diameter wells were seeded with $5 \times 10^{4}$ cells per well, and experiments were carried out between 6 and 10 days postseeding. On the day of the experiment, growth medium was removed from the wells and replaced with Krebs Ringer Bicarbonate (KRB) buffer ( $\mathrm{pH} \mathrm{7.4)} \mathrm{containing} 10 \mathrm{mg} / \mathrm{ml}$ dextrose and $0.1 \mathrm{mg} / \mathrm{ml}$ bovine serum albumin and gassed in $5 \% \mathrm{CO}_{2}$ in air. Preliminary experiments revealed that by varying either extrinsic $\mathrm{Ca}$ or phosphate, the ${ }^{45} \mathrm{Ca}$ exchange difference between $\mathrm{CF}$ and control cells could be amplified. Increasing increments of buffer Ca between $0.5 \mathrm{mM}$ and $2.5 \mathrm{mM}$ or increasing increments of buffer phosphate between $0.5 \mathrm{mM}$ and $5.0 \mathrm{mM}$ caused exchange in cells from subjects with $C F$ and controls to increase. The increase in the CF cells was relatively greater than that in the control cells resulting in an amplified difference between the two groups at the higher concentrations of $\mathrm{Ca}$ or phosphate. Interaction between the $\mathrm{Ca}$ and phosphate levels was not analyzed. Because of this amplification, we added $2.5 \mathrm{mM} \mathrm{CaCl}_{2}$ and 3.0 $\mathrm{mM} \mathrm{KH} \mathrm{PO}_{4}$ to the $\mathrm{KRB}$ routinely. The cells were equilibrated in $\mathrm{KRB}$ in a $37^{\circ} \mathrm{C} \mathrm{CO}_{2}$ incubator for $60 \mathrm{~min}$ in the same $\mathrm{Ca}$ and phosphate concentration that would be present during the ${ }^{45} \mathrm{Ca}$ pulse. This equilibration period assured that the cellular compartments for $\mathrm{Ca}$ approached steady state with the buffer before the introduction of radioactive $\mathrm{Ca}$. The buffer was then removed and identical buffer plus ${ }^{45} \mathrm{Ca}$ at $1 \mu \mathrm{Ci} / \mathrm{ml}$ was added. At each sample period, exchange was stopped by aspirating the buffer from the respective wells and immediate washing of the monolayers with two $3 \mathrm{ml}$ volumes of ice cold wash solution, either phosphate buffered saline (PBS) or $5 \mathrm{mM}$ lanthanum chloride $\left(\mathrm{LaCl}_{3}\right)$ in $0.85 \%$ sodium chloride. $\mathrm{LaCl}_{3}$ in the wash solution removes extracellular and glycocalyx bound ${ }^{45} \mathrm{Ca}$ while preventing any rapid efflux of $\mathrm{Ca}$ from the cell $(25,27)$. At the end of each experiment, wells were harvested by rinsing sequentially with $0.5 \mathrm{ml} 0.1 \mathrm{~N}$ sodium hydroxide, $0.5 \mathrm{ml} 0.1 \mathrm{~N} \mathrm{HCl}$, and $0.5 \mathrm{ml}$ distilled water. All rinses from each well were delivered to a scintillation vial containing $10 \mathrm{ml}$ Aquasol (New England Nuclear, Boston). At least 2 wells per cell line per tray were harvested and used to determine protein per well using a modified Lowry method (23). For some experiments, cell counts per well were determined with a Coulter Counter by harvesting cells in $1 \mathrm{ml}$ of $0.05 \%$ trypsin.

${ }^{45} \mathrm{Ca}$ efflux data were obtained from fibroblasts in both monolayer and suspension systems using the same buffer as in influx experiments. The monolayer efflux experiments utilized the tray and seeding procedures as described for monolayer uptake. Growth medium was replaced with $1 \mathrm{ml} \mathrm{KRB}$ containing ${ }^{45} \mathrm{Ca}$ at $1 \mu \mathrm{Ci} / \mathrm{ml}$. The ${ }^{45} \mathrm{Ca}$ preloading was accomplished during a $90-\mathrm{min}$ equilibration period after which the ${ }^{45} \mathrm{Ca}$ containing medium was removed and the monolayers were washed three times with $3 \mathrm{ml}$ PBS. One ml of KRB without ${ }^{45} \mathrm{Ca}$ was added to each well. At the sample time points, the $1 \mathrm{ml}$ buffer was removed for scintillation counting and was replaced with $1 \mathrm{ml}$ fresh KRB. After the completion of the efflux, cell monolayers were harvested and radioactivity of cells determined as in uptake experiments.

For suspension efflux studies, $6 \times 10^{5}$ cells were seeded in 75 $\mathrm{cm}^{2}$ (\#3024 Falcon, Oxnard, CA) growth flasks and harvested 7 days later by the use of a soft rubber scraper. The cells were washed in $10 \mathrm{ml} \mathrm{KRB}$ and suspended in $13 \mathrm{ml} \mathrm{KRB}$ in plastic tubes (\#2051 Falcon, Oxnard, CA). The buffer for the 90-min equilibration and ${ }^{45} \mathrm{Ca}$ loading period contained $1 \mu \mathrm{Ci}{ }^{45} \mathrm{Ca} / \mathrm{ml}$. A water bath maintained the medium at $37^{\circ}$. Uniform cell suspension was assured by the use of a magnetic stirrer in each tube. Warmed and humidified $5 \% \mathrm{CO}_{2}$ in air was used to maintain $\mathrm{pH}$. After ${ }^{45} \mathrm{Ca}$ loading, the cells were centrifuged, the radioactive buffer poured off, and the cells were washed with $10 \mathrm{ml} \mathrm{KRB}$. Two ml KRB was added to each tube and cells resuspended in this efflux medium. At each time point, the magnetic stirrers were removed and the tubes were centrifuged at $2000 \times g$ for $45 \mathrm{sec}$. The medium from each tube was poured into a scintillation vial for counting in Aquasol and fresh KRB (2 ml) added to the cells. The entire procedure at each time point, from removal of cells from the water bath to resuspension, was accomplished in approximately $60 \mathrm{sec}$. At the completion of the efflux period, the cells were sonicated in $4 \mathrm{ml}$ deionized water and aliquots taken for scintillation counting and protein determination.

Both monolayers and suspension efflux data were analyzed by taking the sum of all time points per minute (cpm) and the final cell cpm as the total radioactivity in the cells at time zero. Each efflux curve was plotted with percent of initial radioactivity left in the cells as a function of time.

Uncontrollable variablility in cell culture experiments is well known $(4,15)$. These experiments were designed to compare $C F$ with control (or carrier with their control) cell lines. Therefore, experiments were performed with cell lines that were matched for age, passage number, day of experiment, multiwell culture tray, and, where possible, sex. This matched-pair design is the most powerful way to control against the random effects of extraneous variables. Comparison of means of samples in these experiments would be inappropriate. The only appropriate statistical tests for data derived from such a design are those comparing pairs of individuals such as matched pair Student's $t$ tests (12). Therefore, matched pair Student's $t$ tests were used with comparisons limited to cell lines on the same multiwell tray or in the case of suspension experiments, limited to matched tubes.

\section{RESULTS}

A representative experiment measuring the exchange over time of ${ }^{45} \mathrm{Ca}$ with cold $\mathrm{Ca}$ is shown in Figure 1 . At $75 \mathrm{~min}$, more intracellular $\mathrm{Ca}$ was replaced by ${ }^{45} \mathrm{Ca}$ in terms of cell protein in the CF sample than in controls. Matched pair analysis revealed that the difference at $75 \mathrm{~min}$ was highly significant (Table 1). In these experiments, cells were washed with phosphate buffered saline.

The experiments in which $\mathrm{LaCl}_{3}$ was used to remove extracellular ${ }^{45} \mathrm{Ca}$ showed differences in ${ }^{45} \mathrm{Ca}$ exchange between $\mathrm{CF}$ and their controls (Table 2) as well as $\mathrm{HZ}$ and their controls (Table 3) at $75 \mathrm{~min}$. Although the total monolayer radioactivity was reduced more than $60 \%$ when using lanthanum washes as compared with PBS washes, the increased ${ }^{45} \mathrm{Ca}$ exchange into both $\mathrm{CF}$ and $\mathrm{HZ}$ cells was apparent and continued to be statistically significant $(P$ $<0.005$ for the CF and control comparison, $P<0.005$ for the $\mathrm{HZ}$ and control comparison). Those experiments in which $\mathrm{HZ}$ and $\mathrm{CF}$

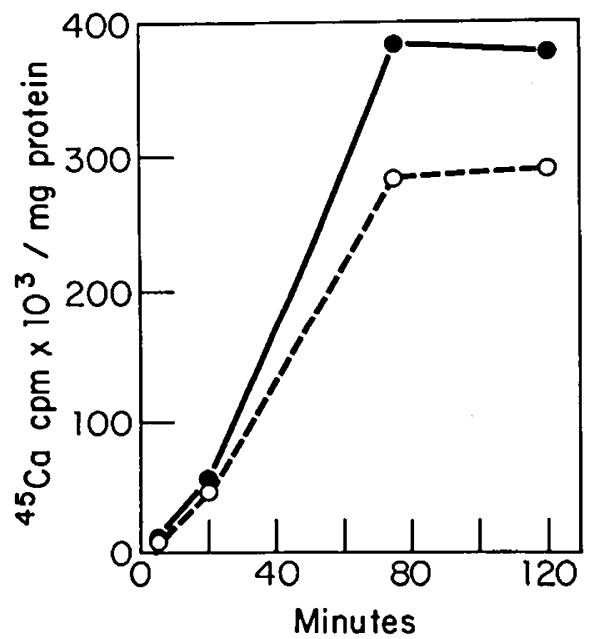

Fig. $1 .{ }^{45} \mathrm{Ca}$ exchange into monolayer cultures of $\mathrm{CF}(\bullet)$ and control $(\mathrm{O})$ fibroblasts. This is a graph of data from a representative experiment. Cells were equilibrated in $\mathrm{KRB}$ buffer containing $2.5 \mathrm{mM} \mathrm{CaCl}_{2}$ and 3.0 $\mathrm{mM} \mathrm{KH} \mathrm{PO}_{4}$ for $1 \mathrm{hr}$ before the addition of fresh buffer containing ${ }^{45} \mathrm{Ca}$ (0-time). Monolayers were washed with cold PBS after the uptake period. 
cells lines were on the same tray (Table 4) showed no differences between $\mathrm{CF}$ and $\mathrm{HZ}$ cells $(P>0.25)$ while both $\mathrm{CF}$ and $\mathrm{HZ}$ differed from the control values $(P<0.01)$.

A representative experiment measuring efflux of ${ }^{45} \mathrm{Ca}$ from preloaded cells in suspension is shown in Figure 2. These curves reveal a change in ${ }^{45} \mathrm{Ca}$ efflux from $\mathrm{CF}$ cells when compared to control cells. Statistical analysis of efflux time points from five matched pair experiments (Table 5) revealed significant differ- ences after $150 \min (P<0.05)$. No differences between $C F$ and control lines were observed in monolayer efflux experiments.

\section{DISCUSSION}

Ca exchange into both $\mathrm{CF}$ and $\mathrm{HZ}$ fibroblast cell lines is clearly greater than exchange into their respective control cells. The difference is observed after the uptake curves plateau indicating

Table $1 .{ }^{45}$ Ca exchange into CF and control fibroblast monolayers (monolayers washed with phosphate buffered saline)

\begin{tabular}{cccccc}
\hline Time (min) & CF mean \pm SE' $^{\prime}$ & Control mean \pm SE' $^{\prime}$ & Pairs & Matched pair Student's $t$ \\
\hline 5 & $9.47 \pm 1.76$ & $8.01 \pm 0.85$ & 12 & 0.8864 & $>0.10$ \\
20 & $58.21 \pm 5.74$ & $46.55 \pm 4.95$ & 12 & 1.657 & 0.07 \\
75 & $279.91 \pm 24.97$ & $208.80 \pm 19.52$ & 12 & 3.779 \\
120 & $346.35 \pm 17.12$ & $246.81 \pm 49.03$ & 2 & 0.005 \\
\hline
\end{tabular}

${ }^{\prime} \mathrm{Cpm} \times 10^{3} / \mathrm{mg}$ protein.

Table 2. ${ }^{45} \mathrm{Ca}$ Exchange into $\mathrm{CF}$ and control fibroblasts 75 min after isotope addition (monolayers washed with LaCl ${ }_{3}{ }^{1}$

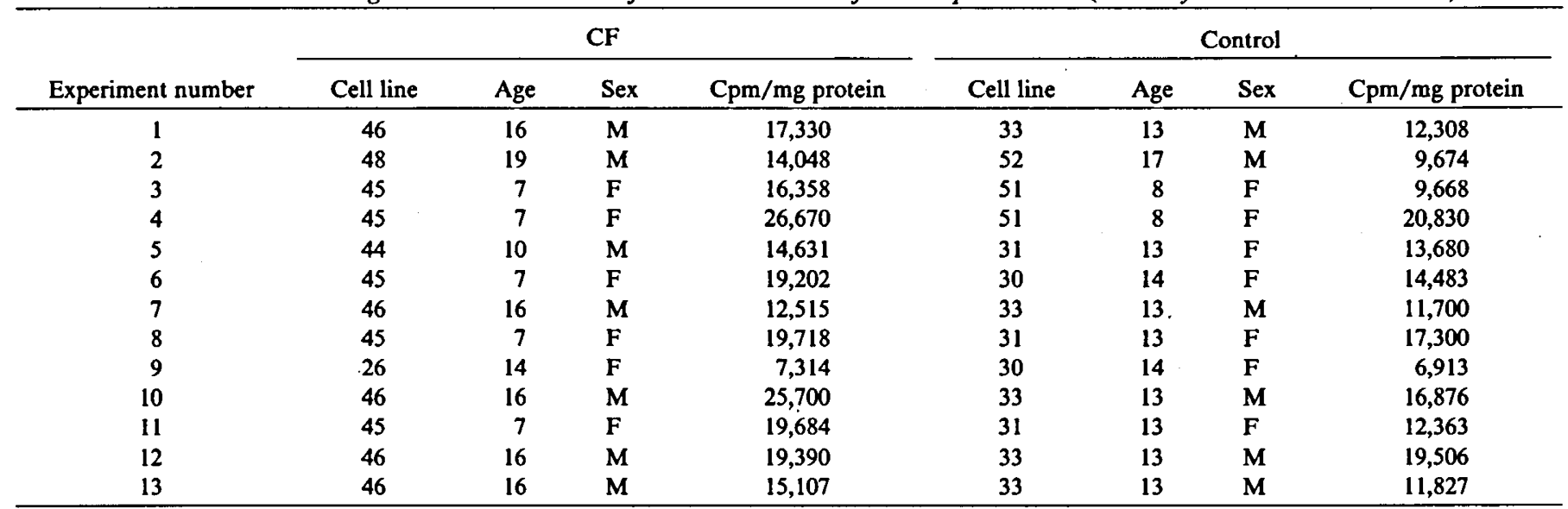

\footnotetext{
' Matched pair comparison $t=4.885, n=13, P<0.005$.
}

Table $3 .{ }^{45} \mathrm{Ca}$ exchange into $\mathrm{HZ}$ and adult control fibroblasts 75 min after isotope addition (monolayers washed with LaCl ( $^{1}$

\begin{tabular}{|c|c|c|c|c|c|c|c|c|}
\hline Experiment number & \multicolumn{4}{|c|}{$\mathbf{H Z}$} & \multicolumn{4}{|c|}{ Control } \\
\hline 1 & 37 & 33 & $\mathbf{F}$ & 7,191 & 40 & 33 & $\mathbf{M}$ & 5,560 \\
\hline 3 & 36 & 28 & $\mathbf{F}$ & 10,782 & 42 & 34 & $\mathbf{F}$ & 9,919 \\
\hline 4 & 36 & 28 & $\mathbf{F}$ & 10,161 & 42 & 34 & $\mathbf{F}$ & 9,402 \\
\hline 5 & 38 & 31 & $\mathbf{F}$ & 8,652 & 40 & 33 & $\mathbf{M}$ & 7,921 \\
\hline 8 & 37 & 33 & $\mathbf{F}$ & 8,377 & 41 & 37 & $\mathbf{F}$ & 7,329 \\
\hline 9 & 38 & 31 & $\mathbf{F}$ & 16,321 & 40 & 33 & $\mathbf{M}$ & 14,096 \\
\hline 10 & 38 & 31 & $\mathbf{F}$ & 13,493 & 42 & 34 & $\mathbf{F}$ & 12,983 \\
\hline 11 & 37 & 33 & $\mathbf{F}$ & 7,526 & 40 & 33 & $\mathbf{M}$ & 6,565 \\
\hline 12 & 37 & 33 & $\mathbf{F}$ & 7,870 & 42 & 34 & $\mathbf{F}$ & 7,176 \\
\hline
\end{tabular}

\footnotetext{
'Matched pair comparison: $t=6.197, n=12, P<0.005$.
}

Table 4. ${ }^{45} \mathrm{Ca}$ exchange into $\mathrm{CF}, \mathrm{HZ}$, and control fibroblasts 75 min after isotope addition (monolayers washed with LaCl ) $^{1}$

\begin{tabular}{|c|c|c|c|c|c|c|c|c|c|c|c|c|}
\hline $\begin{array}{c}\text { Experiment } \\
\text { number }\end{array}$ & \multicolumn{4}{|c|}{$\mathrm{CF}$} & \multicolumn{4}{|c|}{$\mathrm{HZ}$} & \multicolumn{4}{|c|}{ control } \\
\hline 2 & 45 & 7 & $\mathbf{F}$ & 19,684 & 36 & 28 & $\mathbf{F}$ & 16,084 & 31 & 13 & $\mathbf{F}$ & 12,363 \\
\hline 3 & 46 & 16 & $\mathbf{M}$ & 25,700 & 37 & 33 & $\mathbf{F}$ & 15,553 & 33 & 13 & $\mathbf{M}$ & 11,876 \\
\hline 4 & 46 & 16 & $\mathrm{M}$ & 17,330 & 36 & 28 & $\mathrm{~F}$ & 23,059 & 33 & 13 & $\mathbf{M}$ & 12,306 \\
\hline
\end{tabular}

\footnotetext{
'Matched pair comparisons: $n=6$, CF vs. HZ: $t=0.0618, P>0.25$; CF vs. C: $t=2.927, P<0.01$; HZ vs. C: $t=3.102, P<0.01$.
} 


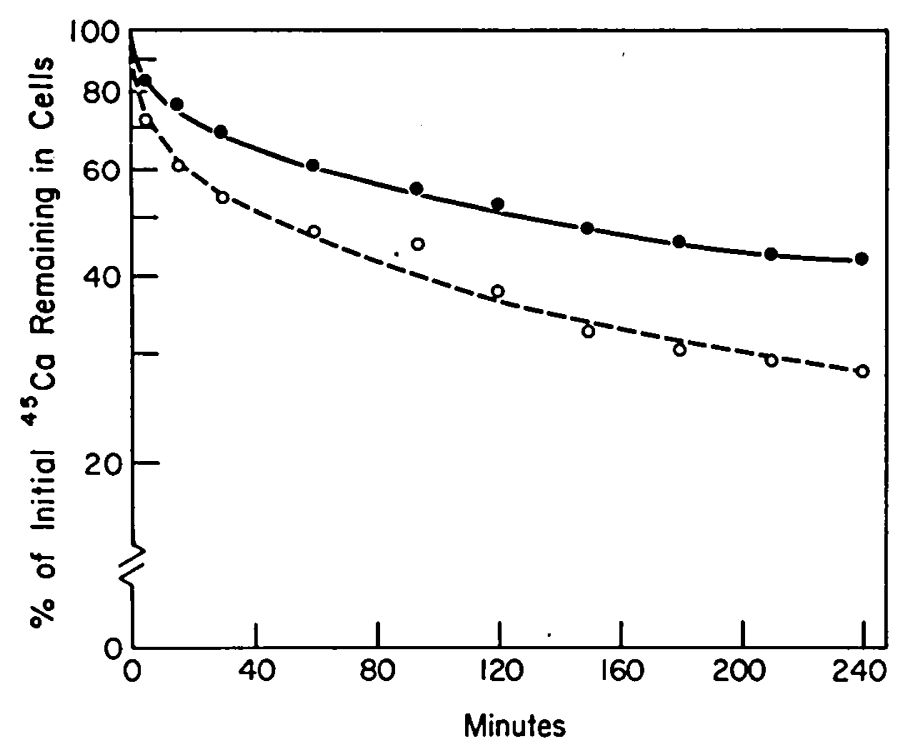

Fig. 2. ${ }^{45} \mathrm{Ca}$ efflux from CF (O) and control $(O)$ fibroblasts. This is a graph of data from a representative experiment. Cells in suspension were prelabeled with ${ }^{45} \mathrm{Ca}$ for $90 \mathrm{~min}$ in $\mathrm{KRB}$ containing $2.5 \mathrm{mM} \mathrm{CaCl}$ and 3.0 $\mathrm{mM} \mathrm{KH} \mathrm{PO}_{4}$, then washed and resuspended in the same buffer without ${ }^{45} \mathrm{Ca}$ for efflux measurements. Each point represents the percent of total (0-time) ${ }^{45} \mathrm{Ca}$ remaining in the cells.

Table 5. Match pair analysis of ${ }^{45} \mathrm{Ca}$ efflux from $\mathrm{CF}$ and control fibroblasts in suspension ( $n=5$ experiments)

\begin{tabular}{ccc}
\hline $\begin{array}{c}\text { Time of efflux } \\
\text { (min) }\end{array}$ & $\begin{array}{c}\text { Matched pair } \\
\text { Student's } t\end{array}$ & $P$ \\
\hline 5 & 0.487 & \\
15 & 0.343 & \\
30 & 0.503 & \\
60 & 1.369 & \\
90 & 1.720 & 0.05 \\
120 & 1.973 & $<0.05$ \\
150 & 2.120 & $<0.025$ \\
180 & 2.543 & $<0.05$ \\
210 & 2.886 & \\
240 & 2.636 & \\
\hline
\end{tabular}

a larger $\mathrm{Ca}$ pool size in the $\mathrm{CF}$ and $\mathrm{HZ}$ cells under these conditions. In order to be assured that possible protein differences between cell lines $(13,26)$ were not influencing the $\mathrm{Ca}$ data, ${ }^{45} \mathrm{Ca}$ exchange was expressed in units of $\mathrm{mg}$ protein and cell number. We found that with respect to either cell number or protein, the intracellular $\mathrm{Ca}$ pool size difference is significant.

While our cell lines were established from age- and sex-matched individuals, seeding for each experiment was done with cell lines randomly obtained from our tissue culture laboratory. Therefore, each experimental pair was not necessarily age-and sex-matched. The ages of matched pairs remained closely comparable because of the matching of the initial groups of individuals. Male to female comparisons within $\mathrm{CF}$ and control groups revealed no differences in $\mathrm{Ca}$ exchange attributable to sex differences.

Any change in cellular $\mathrm{Ca}$ metabolism or binding of the magnitude observed in these experiments (approximately 30\%) is noteworthy. The finding of such a difference in CF cells and particularly in $\mathrm{HZ}$ cells, obtained from individuals who would be undetectable as carriers had they not had a CF child, suggests that altered $\mathrm{Ca}$ metabolism is related to the basic gene defect in CF.

In direct comparison experiments, the $\mathrm{CF}$ and $\mathrm{HZ}$ intracellular pool sizes were not different $(P>0.25)$, and in comparison with their respective control groups, the magnitude of the pool size increase seen in both $\mathrm{CF}$ and $\mathrm{HZ}$ lines were similar. Therefore, in this system, the carriers exhibit the same alteration as do the homozygotes for CF. It is generally assumed that in an autosomal recessive trait a detectable biochemical abnormality in heterozygotes will lie intermediately between the normal and the affected homozygous state. However, with an appropriate challenge to the genetically altered system, the heterozygous and homozygous states may be indistinguishable. For example, at sufficiently low oxygen tension, both homozygotes and heterozygotes for sickle cell hemoglobin will sickle (17). In Ca experiments preliminary to those reported here, it was found necessary to bathe cells with increased $\mathrm{Ca}$ and phosphate concentrations in our experimental media in order to observe consistent differences between CF and controls. The increased medium $\mathrm{Ca}$ or phosphate may be a challenge to a cellular system such that the ${ }^{45} \mathrm{Ca}$ uptake by both $\mathrm{HZ}$ and homozygous $\mathrm{CF}$ cells is essentially equal.

Our early studies on $\mathrm{Ca}$ efflux using monolayer cells showed no difference between CF and control cells (26). However, the suspension experiments showed clear differences of ${ }^{45} \mathrm{Ca}$ efflux. Multiple time point efflux experiments are classically done with cells in suspension (5). In order to measure parameters of the intracellular $\mathrm{Ca}$ sequestering pool or pools, the more readily available glycocalyx and cytoplasmic pools of $\mathrm{Ca}$ must exchange their ${ }^{45} \mathrm{Ca}$ into the media. An explanation for the apparent discrepancy between suspension and monolayer systems may lie in the measurable difference in ${ }^{45} \mathrm{Ca}$ efflux efficiency between suspension and monolayer experiments. In monolayer experiments, the percent of initial cellular ${ }^{45} \mathrm{Ca}$ left in cells after $4 \mathrm{hr}$ of efflux never fell below $75 \%$, while in suspension experiments this value approached $20 \%$. The less efficient efflux seen in monolayer cells may have prevented detection of the difference observed in suspension.

Although there are no obvious morphologic or biochemical observations in CF fibroblasts to account for the observed $\mathrm{Ca}$ differences, several lines of evidence suggest that the altered $\mathrm{Ca}$ pool size is located in an intracellular $\mathrm{Ca}$ sequestering organelle system. When the extracellular and glycocalyx bound ${ }^{45} \mathrm{Ca}$ was removed with $\mathrm{LaCl}_{3}$ washes, differences of approximately $30 \%$ were noted suggesting that the site of the difference is intracellular. Because the major portion of intracellular $\mathrm{Ca}$ is sequestered in organelles such as mitochondria (5) and microsomes (22), these are likely the site of the large pool size difference observed. This explanation for the data is supported by the fact that increased concentrations of $\mathrm{Ca}$ or phosphate ions in the experimental buffer amplified the difference between CF and control cells (see Materials and Methods) suggesting that the altered pool is one capable of sequestering high concentrations of $\mathrm{Ca}$ and phosphate or one which is sensitive to $\mathrm{Ca}$ or phosphate ion concentration. Ca uptake by mitochondria in vitro is greatly enhanced by the presence of phosphate as a permeant anion (18). Mitochondria in vivo have been shown to be capable of large accumulations of $\mathrm{Ca}$ in the form of calcium phosphate granules (6). Finally, data from the ${ }^{45} \mathrm{Ca}$ efflux experiments on cells in suspension show that the larger percent of initial ${ }^{45} \mathrm{Ca}$ remains in the CF cells as compared with controls. This suggests that, with our experimental conditions, a cellular calcium pool with slow efflux parameters such as mitochondria (6) contains more $\mathrm{Ca}$ in $\mathrm{CF}$ than in control cells.

This $\mathrm{Ca}$ pool size difference, while not characterized, is a consistent finding in repeated experiments comparing $\mathrm{CF}$ and $\mathrm{HZ}$ cells with their respective controls. The fact that the $\mathrm{Ca}$ pool size alteration is found using cells in vitro is strong evidence against the possibility that $\mathrm{Ca}$ differences are secondary to the disease process or treatment. The clear and consistent $\mathrm{Ca}$ pool size difference in $\mathrm{HZ}$ cells suggests the $\mathrm{Ca}$ alteration is not far removed from the abnormal gene product in CF.

\section{REFERENCES AND NOTES}

1. Baur, P. S., Bolton, W. E., and Barranco, S. C.: Electron microscopy and microchemical analysis of cystic fibrosis diploid fibroblasts in vitro. Texas Rep. Biol. Med., 34: 113 (1976).

2. Blomfield, J., Warton, K. L., and Brown, J. M.: Flow rate and inorganic components of submandibular saliva in cystic fibrosis. Arch. Dis. Children, 48: 267 (1973). 
3. Bogart, B. I.: The biologic activities of cystic fibrosis serum. I. The effect of cystic fibrosis sera and calcium ionophore A23187 on rabbit tracheal explants. Pediatr. Res., 11: 131 (1977).

4. Bolton, W. E., and Barranco, S. C.: Review of the growth characteristics of cystic fibrosis and normal human diploid fibroblasts in vitro. Texas Rep. Biol. Med., 34: 97 (1976).

5. Borle, A. B.: Methods for assessing hormone effects on calcium fluxes in vitro. Methods Enzymol., 39: 513 (1975).

6. Borle, A. B., and Anderson, J. H.: Control and regulation of calcium homeostasis and transport. Calcif. Tissue Res., 21 Suppl.: 21 (1976).

7. Botelho, S. Y., Goldstein, A. M., and Rosenlund, M. L.: Tear sodium, potassium, chloride, and calcium at various flow rates: children with cystic fibrosis and unaffected siblings with and without corneal staining. J. Pediatr. 83: 601 (1973).

8. Carafoli, E.: Mitochondrial uptake of calcium ions and the regulation of cell function. Biochem. Soc. Symp., 39: 89 (1974).

9. DiSant 'Agnese, P. A., and Davis, P. B.: Research in cystic fibrosis. N. Engl. J. Med., 295: 481 (1976).

10. DiSant 'Agnese, P. A., and Talamo, R. C.: Pathogenesis and physiopathology of the cystic fibrosis of the pancreas. N. Engl. J. Med., 277: 1287 (1967).

11. Douglas, W. W.: The role of calcium in stimulus-secretion coupling, In: R. M. Case, and H. Goebell; Stimulus-Secretion Coupling In The Gastrointestinal Tract. p. 17 (University Park Press, Baltimore, 1976).

12. Dunn, O. J.: In: Basic statistics: A Primer For The Biomedical Sciences. p. 72 (Wiley, New York, 1964).

13. Farrell, P. M., Pallavicinni, J. C., and Ulane, M. M.: Growth characteristics and protein content of tissue-cultured fibroblasts from cystic fibrosis patients. Proc. Soc. Exptl. Biol. Med., 149: 340 (1975).

14. Fletcher, D. S., and Lin, T, Y.: Incorporation of L-leucine and D-glucosamine into skin fibroblasts derived from cystic fibrosis and normal individuals. Clin. Chim. Acta, 44: 5 (1973).

15. Foster, D. O., and Pardee, A. B.: Transport of amino acids by confluent and nonconfluent 3T3 and polyoma virus-transformed 3T3 cells growing on glass cover slips. J. Biol. Chem., 244: 2675 (1969).

16. Gibson, L. E., Matthews, W. J., Jr., Minihan, P. T., and Patti, J. A.: Relating mucus, calcium, and sweat in a new concept of cystic fibrosis. Pediatrics, 48: 695 (1971).

17. Lehmann, H., and Huntsman, R. G.: The hemoglobinopathies, In: J. B. Stanbury, J. B. Wyngaarden, and D. S. Fredrickson: The Metabolic Basis of Inherited Disease; pp. 1398-1431 (McGraw-Hill, Inc., New York, 1972).

Copyright (C) 1979 International Pediatric Research Foundation, Inc. $0031-3998 / 79 / 1306-0764 \$ 02.00 / 0$
18. Lehninger, A. L.: Role of phosphate and other proton-donating anions in respiration-coupled transport of $\mathrm{Ca}^{2+}$ by mitochondria. Proc. Natl. Acad. Sci., 71: 1520 (1974).

19. Lehninger, A. L., Carafoli, E., and Rossi, C. S.: Energy-linked ion movements in mitochondrial systems. Adv. Immunol., 29: 259 (1967).

20. Lobeck, C. C.: Cystic fibrosis. In: J. B. Stanbury, J. B. Wyngaarden, and D. S. Fredrickson: The Metabolic Basis of Inherited Disease. pp. 1605-1626 (McGraw-Hill, Inc., New York, 1972)

21. Mangos, J. A.: Cystic Fibrosis, In: T. E. Adreoli, J. F. Hoffman, D. D. Fanestil: Physiology of Membrane Disorders. p. $941-953$ (Plenum Medical, New York, N.Y., 1978).

22. Moore, L., and Pastan, I.: Regulation of intracellular calcium in chick embryo fibroblasts: calcium uptake by the microsomal fraction. J. Cell Physiol., 91: 289 (1977).

23. Oyama, V. I., and Eagle, H.: Measurement of cell growth in tissue culture with a phenol reagent (Folin-Ciocalteau). Proc. Soc. Exptl. Biol. Med., 91: 305 (1956).

24. Rasmussen, H., Goodman, D. B. P., and Tenenhouse, A.: The role of cyclic AMP and calcium in cell activation. Crit. Rev. Biochem., 1: 95 (1972).

25. Robblee, L. S., and Shepro, D.: The effect of external calcium and lanthanum on platelet content and on the release reaction. Biochim. Biophys. Acta, 436: 448 (1976).

26. Shapiro, B. L., Feigal, R. J., Laible, N. J., Biros, M. H., and Warwick, W. J.: Doubling time, $\alpha$-aminoisobutyrate transport and calcium exchange in cultured fibroblasts from cystic fibrosis and control subjects. Clin. Chim. Acta, 82: 125 (1978).

27. VanBreeman, C., Farinas, B. R., Gerba, P., and McNaughton, E. D.: Excitationcontraction coupling in rabbit aorta studied by the lanthanum method for measuring cellular calcium influx. Circ. Res., 33: 44 (1972).

28. Wotman, S., Mandel, I. D., Mercadante, J., and Denning, C. R.: Parotid and submaxillary calcium in human cystic fibrosis. Arch. Oral Biol., 16: 663 (1971).

29. The authors thank Dr. Warren Warwick for helping to provide access to clinical materials. We thank Ms. Nancy Laible for invaluable technical support in our tissue culture laboratory.

30. This research was supported by a State of Minnesota Special Allocation for Cystic Fibrosis Research, NIH Grant DE-00005 and the Cystic Fibrosis Foundation.

31. Received for publication April 7, 1978.

32. Accepted for publication June $29,1978$. 